\title{
História das ideias linguísticas por meio das crônicas de Machado de Assis
}

\author{
Agnaldo Martino ${ }^{1}$
}

\section{Considerações iniciais}

M achado de Assis produziu uma obra variada e profícua: escreveu romances, 1 contos, poemas, peças teatrais, críticas literárias e crônicas.

Considerado um dos maiores escritores não só dentre os brasileiros, mas também dentre os estrangeiros, todos veem em seu texto as qualidades do bom redator: aquele que organiza as palavras, as frases, os parágrafos de forma magistral e soberana. Evanildo Bechara - em conversa com a jornalista Maria Cláudia de Mesquita, no vídeo produzido pelo Centro de Memória da Academia Brasileira de Letras e apresentado no Colóquio Machado de Assis, realizado pela Fundação Calouste Gulbenkian, em Lisboa ${ }^{2}$ - diz:

1 Pós-doutorando em Língua Portuguesa, pela Pontifícia Universidade Católica de São Paulo - PUC/SP. Membro do Grupo de Pesquisa de História das Ideias Linguísticas (Brasil e Portugal) e Identidade Nacional da PUC-SP, coordenado pela Prof ${ }^{a}$ Dra Leonor Lopes Fávero. Contato: agnaldomartino@gmail.com

2 Informações sobre o Colóquio Machado de Assis estão disponíveis no site da Fundação Calouste Gulbenkian: http://www.gulbenkian.pt/section54artId950langId1.html (acesso em 07/11/2012). 
Todos nós tínhamos uma ideia de que o léxico de Machado de Assis seria em torno de duas a três mil palavras. Agora, com as comemorações do centenário, propusemos fazer um levantamento e ficamos curiosos, porque já recolhemos quase nove mil palavras diferentes. É um léxico corrente, mas rico. ${ }^{3}$

Os romances e contos machadianos, objetos de estudo de muitos trabalhos acadêmicos, revelam os costumes, a organização e a cultura do Rio de Janeiro no século XIX, assim como estudam tipos humanos e suas relações interpessoais.

Já por meio de suas crônicas, Machado de Assis expressava sua opinião a respeito de diversos temas do dia a dia, que afetavam não só o Rio de Janeiro, mas toda a nação brasileira. Ele comentava um pouco de tudo - economia, política, cultura, educação, artes, espetáculos etc. -, e em algumas delas teceu comentários acerca da língua portuguesa.

Por sempre tratar de assunto do dia a dia, a crônica depende de um conhecimento de época que, hoje, só se obtém com alguma pesquisa. Talvez por isso não seja objeto frequente de análise.

Até meados do século passado, as crônicas eram consideradas por muitos estudiosos "gênero menor". Candido (1992), fazendo um estudo sobre o gênero, começa seu texto afirmando:

A crônica não é um "gênero maior". Não se imagina uma literatura feita de grandes cronistas, que lhe dessem o brilho universal dos grandes romancistas, dramaturgos e poetas. Nem se pensaria em atribuir o Prêmio Nobel a um cronista, por melhor que fosse. Portanto, parece mesmo que a crônica é um gênero menor. (CANDIDO, 1992, p.13)

Para logo adiante, afirmar sua real visão sobre a crônica:

Ora, a crônica está sempre ajudando a estabelecer ou restabelecer a dimensão das coisas e das pessoas. Em lugar de oferecer um cenário excelso, numa revoada de adjetivos e períodos candentes, pega o miúdo e mostra nela uma grandeza, uma beleza ou uma singularidade insuspeitadas. Ela é amiga da verdade e da poesia nas formas mais diretas e também nas formas mais fantásticas [...]. (idem, p. 14)

3 "O amor de Machado de Assis pela Língua Portuguesa" - Evanildo Bechara, videodepoimento - Academia Brasileira de Letras, 2008 
A visão que se tem hodiernamente sobre a crônica é outra: faz parte da literatura tanto quanto um conto, um romance, uma poesia também o fazem.

O estudo das crônicas, obras ditas "menores", de Machado de Assis é de grande importância, inclusive para entender os seus romances e contos (obras mais amplas), pois é por meio delas que se constrói a imagem do quotidiano do século XIX, e - por conseguinte - dos personagens apresentados pelo autor.

Para compreender toda a extensão de uma crônica (não apenas as de $\mathrm{Ma}$ chado de Assis, mas toda e qualquer crônica - antiga ou moderna), é necessário entender não só os eventos históricos que foram o contexto delas, mas também ler os jornais, para saber quais os eventos mínimos, os acontecimentos desimportantes do dia, e que - de um jeito ou de outro - foram temas para as crônicas.

\section{A literatura como documento histórico}

Seguindo as bases teóricas de Chartier (1990), a análise pelo viés da História das Ideias Linguísticas, se faz pelos princípios de apropriação e representação, conjugando as ideias desse estudioso com as de Pesavento (2006), por meio das quais tomamos a literatura como fonte histórica.

A literatura é, fundamentalmente, fonte de si mesma, isto é, os historiadores não devem reduzir os textos literários a simples documentos. É importante entender de que maneira a criação estética se apropria dos objetos, das práticas ou dos códigos de sua época para transformá-los em obras literárias. A força da literatura não está na comprovação de sua verdade, está nas ideias consegue transmitir, e, assim, produzir, em seus espectadores ou leitores, novas maneiras de perceber ou pensar. A tarefa do pesquisador é reconhecer a força de tais representações e, simultaneamente, propor, a partir de seus critérios de trabalho, um conhecimento do passado fundamentado na interpretação crítica e científica dessa fonte histórica, que é a literatura.

A tradição da história social esquece que a construção das identidades não se reduz apenas aos critérios objetivos da riqueza, das ocupações, da propriedade, mas a construção da identidade engloba também as lutas que apostam nas divisões, classificações, hierarquias do mundo social; a tradição histórica pensa a noção de "mentalidade" como homogênea e rígida. O conceito de representação surge a partir dessas críticas, pois a representação deve permitir que se defina, claramente, para cada grupo social ou classe, as representações coletivas que cabem às estruturas do mundo social, aos indivíduos, e à construção dos comportamentos e hábitos encarregados de mostrar uma identidade. Isso representa uma nova forma de fazer História. 
Esse novo enfoque para a História modifica, então, o conceito de "documento" histórico, ampliando-o a outras esferas; a partir disso, os objetos dos quais podemos nos apoderar são textos canônicos ou não, obras clássicas ou sem méritos, mas também a produção iconográfica em todas suas formas, a música, o canto, e todas as formas que se ligam à palavra viva. São objetos legítimos, fundamentais e articulados da Nova História Cultural. E, para se aproximar destes objetos, existem os documentos, que também pertencem a todas essas ordens, inclusive os objetos materiais deixados pelo passado ou os espaços existenciais encontrados numa cidade ou em outros espaços como grandes casas, castelos etc. Desse modo, o desafio essencial seria, por um lado, evitar uma leitura das obras estéticas como documentos, isto é, como se refletissem imediatamente uma realidade social - que foi uma tentação dos historiadores ao reduzir a obra literária a seu conteúdo de documento. Assim, devemos nos acercar da prática da representação para poder dizer algo da representação das práticas.

Por outro lado, há também a possibilidade, caso não se reduzam as obras ao estatuto de documento, de mobilizar os documentos tradicionais ou novos da história para nos aproximar deste mistério que é a apropriação, a construção do sentido de comunidades de leitores frente a obras, quaisquer que sejam. E isso se torna um jogo entre obras e documentos - evitando a redução de um a outro - que pode definir este tipo de trabalho histórico.

Em nossa sociedade, o presente se apropria tanto do passado, transformando-o em memória, quanto do futuro, considerado como promessas. Assim, a tarefa do pesquisador é recordar que esse presente todo-poderoso está alicerçado em milhares de heranças, sedimentadas e contraditórias, e que cada pessoa é um ser histórico que incorporou várias histórias, desde a mais recente e individual até a mais antiga e coletiva.

Machado de Assis é esse "historiador do presente" em seu tempo ao escrever suas crônicas, que, para nós hoje, são fontes históricas, pois descrevem um período muito importante da história do Brasil: a segunda metade do século XIX, marcada por profundas mudanças sociais.

As análises feitas por Machado de Assis, nessas crônicas, mostram um aprimoramento na arte de radiografar a sociedade brasileira, em especial a do Rio de Janeiro, apontando seus vícios e virtudes, e funcionando como testemunho de uma época. De acordo com Faria (2008),

Antes de se dedicar mais intensamente à atividade literária que o consagrou, Machado tornou-se conhecido como folhetinista, crítico teatral, crítico literário, comediógrafo, poeta, tradutor - de 
poemas, peças teatrais e romances - e até mesmo como censor do Conservatório Dramático. Os amigos admiravam a inteligência e o brilho do rapaz pobre que começara como tipógrafo e já na casa dos vinte anos de idade era uma peça-chave no debate cultural do seu tempo, com intervenções corajosas e por vezes contundentes nos textos críticos e nos folhetins que publicava em vários jornais do Rio de Janeiro. (FARIA, 2008, p. 21)

Machado exerceu regularmente a função de cronista nos mais diversos periódicos fluminenses, por mais de quarenta anos entre 1858 e 1900; escreveu para O Espelho, Diário do Rio de Janeiro, Semana Ilustrada, O Futuro, Ilustração Brasileira, O Cruzeiro e Gazeta de Notícias. Ele produziu mais de 600 crônicas, tratando dos mais variados assuntos.

A crítica tradicional da obra machadiana, em sua grande maioria, não se ocupa em estudar as crônicas de Machado de Assis, sob o viés de destacá-lo como um observador crítico da situação linguística do Brasil de sua época. Parece-nos que a ideia de crônica como "gênero menor" contribui para que seja ignorada ou minimamente analisada pelos críticos. Entretanto, Candido (1992) lembra que o escritor colaborou com o amadurecimento da crônica no país, abrasileirando esta expressão híbrida entre o jornalismo e a literatura. Arrigucci Jr. (1985) considera que Machado de Assis, ao praticar o folhetim, mostra-se escriba de coisas miúdas, e comenta:

Machado se afina pelo tom menor que será, daí para frente, o da crônica brasileira, voltada para as miudezas do cotidiano, onde acha a graça espontânea do povo, as fraturas expostas da vida social, a finura dos perfis psicológicos, o quadro dos costumes, o ridículo de cada dia e até a poesia mais alta que ela chega alcançar [...]. (ARRIGUCCI JR., 1985, p. 48).

Tanto Candido quanto Arrigucci Jr. oferecem uma crítica panorâmica sobre a crônica machadiana. Porém, alguns autores se dedicaram, sim, a temas específicos retratados por Machado em suas crônicas, tais como Gledson (1986) - que realiza uma densa leitura alegórica das crônicas de Machado que tratam da questão da "Abolição", refutando a velha opinião de que o nosso escritor teria ficado alheio às questões políticas e sociais do seu tempo -; Faria (2008, p. 15) - que reúne "um valioso conjunto de textos que permitem acompanhar, ano a ano, o grau de envolvimento de Machado 
com o teatro, desde a juventude até a velhice." -; ou Franco (2007, p.13) - que pesquisa a economia nas crônicas machadianas:

Esta é uma antologia temática, em que se busca o olhar de Machado de Assis, o cronista, sobre eventos econômicos e financeiros de seu tempo, os principais acontecimentos paradigmáticos de uma época tumultuada, mas também os secundários, os pequenos dramas anônimos e cotidianos que fornecem preciosas alegorias para enredos maiores. Com efeito ninguém melhor que este cronista para destilar a grandeza do aparentemente efêmero, e dos aspectos laterais e reveladores de nossas complexas e nada óbvias inflexões históricas.

Hoje, tomamos contato com a língua portuguesa do século XIX pesquisando as gramáticas, os estudos críticos linguísticos, a crítica literária, os planos de estudos de colégio como os do Colégio Pedro II - que era referência no ensino secundário -, mas o que pretendemos aqui neste trabalho é conhecer um pouco mais da História das Ideias Linguísticas e da Identidade Nacional pela visão de um dos maiores escritores daquele tempo.

\section{A construção da crônica machadiana}

Machado de Assis viveu seus sessenta e nove anos na cidade do Rio de Janeiro, presenciando os grandes acontecimentos da segunda metade do século XIX e refletindo sobre eles em suas crônicas, por isso - para que tenhamos uma visão mais ampla a respeito daquilo que escreveu nosso autor - é imprescindível conhecer o contexto histórico desse período, principalmente sobre a cidade do Rio de Janeiro, uma vez que, de acordo com as ideias de Sevcenko (1983, p.117),

[...] desde praticamente o início da campanha abolicionista até o início da década de 1920, quase toda produção literária nacional se fazia no Rio de Janeiro, voltada para aquela cidade ou tomando-a em conta. Palco principal de todo esse processo radical de mudança, a capital centralizou ainda os principais acontecimentos desde a desestabilização paulatina do Império até a consolidação definitiva da ordem republicana. Ela concentrava também o maior mercado de emprego para os homens de letras. Sua posição de proeminência se consagrou definitivamente em 1897, com a inauguração ali da Academia Brasileira de Letras.

Um dos traços estilísticos de Machado de Assis é o hábito de enunciar opiniões ou emitir comentários sobre a linguagem empregada por ele em suas crônicas 
(e também em seus textos ficcionais). Dotado de apurado senso de percepção linguística, Machado utiliza-se da metalinguagem para tecer reflexões sobre seus meios de expressão, o que equivale a dizer: sobre questões de língua, de estilo, de autocrítica e, ainda, de interação com seu leitor. Da mesma forma que faz comentários sobre seus meios de expressão, ele também costuma comentar seu processo de composição textual. Assim, o nosso exímio e competente escritor, não apenas faz literatura, mas também ensina a fazê-la.

As crônicas de $1^{\circ}$ de novembro 1877, 5 de abril de 1888 e 16 de setembro de 1894 - apresentadas abaixo, respectivamente - são marcadas pelo exercício da metalinguagem:

Há um meio certo de começar a crônica por uma trivialidade. É dizer:

que calor! Que desenfreado calor! Diz-se isto, agitando as pontas do lenço, bufando como um touro, ou simplesmente sacudindo a sobrecasaca. Resvala-se do calor aos fenômenos atmosféricos, fazem-se algumas conjeturas acerca do sol e da lua, outras sobre a febre amarela, manda-se um suspiro a Petrópolis, e la glace est rompue; está começada a crônica. (ASSIS, 2008c: 385).

Hão de reconhecer que sou bem-criado. Podia entrar aqui, chapéu à banda, e ir dizendo o que me parecesse; depois ia-me embora, para voltar na outra semana. Mas não, senhor; chego à porta, e o meu primeiro cuidado é dar-lhe os bons dias. Agora, se o leitor não me disser a mesma coisa, em resposta, é porque é um grande malcriado, um grosseirão de borla e capelo; ficando, todavia, entendido que há leitor e leitor, e que eu, explicando-me com tão nobre franqueza, não me refiro ao leitor, que está agora com este papel na mão, mas ao seu vizinho. Ora bem! (ASSIS, 2008c, p. 801)

Que boas são as semanas pobres! As semanas ricas são ruidosas e enfeitadas, aborrecíveis em suma. Uma semana pobre chega à porta do gabinete, humilde e medrosa:

Meu caro senhor, eu pouco tenho que lhe dar. Trago as algibeiras vazias; quando muito, tenho aqui esta cabeça quebrada, a cabeça do Matias...

Mas que quero eu mais, minha amiga? Uma cabeça é um mundo... Matias, que Matias? 
Matias, o leiloeiro que passava ontem pela rua de São José, escorregou e caiu... Foi uma casca de banana.

Mas há cascas de banana na rua de São José?

Onde é que não há cascas de bananas? Nem no céu, onde não se come outra fruta, com toda certeza, que é fruta celestial. Mate-me Deus com bananas. Gosto delas cruas, com queijo de Minas, assadas com açúcar, açúcar e canela... Dizem que é muito nutritiva.

Confirmo este parecer, e aí vamos nós, eu e a semana pobre, papel abaixo, falando de mil coisas que se ligam à banana, desde a botânica até a política. Tudo sai da cabeça do Matias. Não há tempo nem espaço, há só eternidade e infinito, que nos levam consigo; vamos pegando aqui de uma flor, ali de uma pedra, uma estrela, um raio, os cabelos da Medusa, as pontas do diabo, micróbios e beijos, todos os beijos que se têm consumido neste mundo, todos os micróbios que nos têm consumido, até que damos por nós no fim do papel. São assim as semanas pobres.

Mas as semanas ricas! Uma semana como esta que ontem acabou, farta de sucessos, de aventuras, de palavras, uma semana em que até o câmbio começou a esticar o pescoço pode ser boa para quem gosta de bulha e de acontecimentos. Para mim que amo o sossego e a paz é a pior de todas as visitas. As semanas ricas exigem várias cerimônias, algum serviço, muitas cortesias.

Demais, são trapalhonas, despejam as algibeiras sem ordem e a gente não sabe por onde lhe pegue, tantas e tais são as coisas que trazem consigo. Não há tempo de fazer estilo com elas, nem abrir a porta à imaginação. Todo ele é pouco para acudir os fatos. (ASSIS, 2008b, p.1102-3)

Machado de Assis aproveita-se de algumas oportunidades para discorrer a respeito da origem do gênero, para apresentar a maneira como se deve proceder em tal texto, assim como para caracterizar as estratégias utilizadas na observação e julgamento dos fatos da semana. Ele, com isso, busca compartilhar com o leitor o seu estilo de fazer crônica, apresentando certas particularidades no trato com o público, deixando explícitas suas preferências temáticas, pois nem tudo o que é destaque no noticiário é de seu agrado. Apreende-se da leitura dessas crônicas que, antes de se lançar às discussões sobre os vários temas sociais, foi necessário a ele conhecer o funcionamento do gênero que marcou a expressão 
jornalística do século XIX: a crônica. Explicando esses meandros, nosso autor pretende mostrar ao leitor os princípios norteadores do ofício dos cronistas.

Machado de Assis inicia a crônica de $1^{\circ}$ de novembro de 1877 com uma divagação sobre o surgimento do gênero, conta algo que pode ser, a princípio, trivial e comezinho, mas "em busca do pitoresco ou do irrisório no cotidiano de cada um" (SABINO, 1965, p. 174). O cronista procura - com tal ação -, como salienta Moisés (1970, p.247), "desentranhar do acontecimento sua porção imanente de fantasia". Machado parte do princípio de que a crônica começa despretensiosa, como quem não quer nada, para depois abraçar o mundo, por meio de palpites sobre todo e qualquer assunto.

Em 1877, aos 38 anos de idade - já como um autor reconhecido -, ele retoma o painel que havia traçado em 1859 , aos vinte anos de idade, sobre o ofício do cronista e de sua liberdade em atuar nos diversos assuntos:

O folhetinista, na sociedade, ocupa o lugar de colibri na esfera vegetal; salta, esvoaça, brinca, tremula, paira e espaneja-se sobre todos os caules suculentos, sobre todas as seivas vigorosas. Todo o mundo lhe pertence; até mesmo a política. (ASSIS, 2008b, p. 1022-3)

Trata-se de um retorno às origens, revivendo o que marcou, desde o princípio da carreira, o seu ingresso na discussão sobre o exercício da própria profissão. Pode-se dizer que o cronista, agindo desse modo, conseguiu "atar as duas pontas da vida", tal como desejou Bentinho, personagem da ficção machadiana, ao escrever seu livro de memórias.

\section{A vida quotidiana}

Hoje se admite que a História não é apenas o registro dos grandes feitos dos grandes homens. Modernamente, fazemos História pela percepção de atos do quotidiano, de pessoas comuns e acontecimentos comuns, pois é assim que se entendem melhor as transformações pelas quais o mundo passa.

A vida cotidiana é a vida de todo homem. Todos a vivem, sem nenhuma exceção, qualquer que seja seu posto na divisão do trabalho intelectual e físico. Ninguém consegue identificar-se com a sua atividade humano-genérica a ponto de poder desligar-se inteiramente da cotidianidade. 
A vida cotidiana não está "fora" da história, mas no "centro" do acontecimento histórico: é a verdadeira "essência" da substância social. (HELLER, 2008, p.31 e 34)

Partindo desse princípio, mostram-se a seguir fatos e dados da vida na cidade do Rio de Janeiro, e as mudanças pelas quais essa cidade passou, adaptando-se aos novos tempos da segunda metade do século XIX.

No século XIX, as principais transformações sociais aconteciam no Rio de Janeiro. O Rio era o foco da atenção de todo o país. Os acontecimentos, quaisquer que fossem, assumiam uma "importância desmedida em função da ressonância produzida pela situação privilegiada em que se achava a cidade" (cf. CARVALHO, 1991, p. 22).

Era, portanto, cada vez mais atraente morar na cidade do Rio de Janeiro. Aluísio Azevedo, em Casa de Pensão, diz justamente isso, por meio do personagem "Amâncio":

A Corte era "uma Paris", diziam na província, e ele, por conseguinte, havia de lá encontrar boas aventuras, cenas imprevistas, impressões novas e amores, - oh! amores principalmente. (AZEVEDO, 1973, p. 50)

A imagem de Paris impunha-se como sentido de refinamento. Essa cidade, plena de processos socialmente inovadores, era - por excelência - modelo da civilização e das transformações que se instalavam no Brasil.

Na primeira época do reinado de d. Pedro II, entre 1840 e 1867, até a Guerra do Paraguai, copiava-se tanto os esplendores do Segundo Império francês, quanto os seus maus costumes. Paris dominava o mundo. o Rio de

Janeiro contagiava-se por imitação. (DEL PRIORE, 2011, p. 71)

O rápido crescimento populacional do Rio de Janeiro contribuía também para alterar-lhe o perfil, pois a abolição da escravatura lançava no mercado de trabalho livre o restante da mão de obra escrava, impulsionando-a para os núcleos urbanos mais desenvolvidos. Assim, tornava-se um polo de atração tanto para o trabalhador assalariado das regiões brasileiras em declínio quanto para os imigrantes estrangeiros, especialmente os portugueses.

Em 1872, a cidade do Rio contava com uma população de 274.972 habitantes, sendo que 190.689 era de nacionalidade brasileira e 84.283 de nacionalidade estrangeira - ou seja, 30,65\% da população era de estrangeiros. Em 1890, o 
movimento migratório continuava: de uma população de 522.651 habitantes, 398.299 era de nacionalidade brasileira e 124.352 de nacionalidade estrangeira, estes correspondendo a $23,79 \%$ da população ${ }^{4}$. Tais dados evidenciam que a cidade abrigava uma quantidade expressiva de imigrantes, o que provocava mudanças culturais: diferentes visões de mundo conviviam e fundiam-se no mesmo espaço social, regendo a cidade e redefinindo padrões de comportamento.

A cidade se ajustava progressivamente a essa crescente população: a iluminação a gás, a água encanada, as estradas de ferro e os bondes elétricos simbolizavam a prosperidade. Em 1877, Machado de Assis escreveu:

Mas inauguraram-se os bonds. Agora é que Santa Teresa vai ficar à moda. O que havia pior, enfadonho a mais não ser, eram as viagens de diligência, nome irônico de todos os veículos desse gênero. A diligência é um meio-termo entre a tartaruga e o boi.

Uma das vantagens dos bonds de Santa Teresa sobre os seus congêneres da cidade, é a impossibilidade da pescaria. A pescaria é a chaga dos outros bonds. Assim, entre o Largo do Machado e a Glória a pescaria é uma verdadeira amolação, cada bond desce a passo lento, a olhar para um e outro lado, a catar um passageiro ao longe. Às vezes o passageiro aponta na Praia do Flamengo, o bond, polido e generoso, suspende passo, cochila, toma uma pitada, dá dois dedos de conversa, apanha o passageiro, e segue o fadário até a seguinte esquina onde repete a mesma lengalenga.

Nada disso em Santa Teresa: ali o bond é um verdadeiro leva-e-traz, não se detém a brincar no caminho, como um estudante vadio. (ASSIS, $2008^{\mathrm{a}}$, p.353)

Os bondes elétricos diminuíam as distâncias e provocavam a socialização entre os seus usuários; com o uso deles, podia-se fazer passeios a lugares ainda pouco urbanizados.

Gradativamente os hábitos da cidade iam-se modificando, exigindo de seus habitantes novas formas de convívio. Ocorria, por exemplo, a quebra de barreira entre as casas e as ruas: estas, pertencentes aos escravos, agora "são frequentadas por famílias a passeio e mesmo senhoras que já dispensavam o séquito de mucamas" (cf. BASBAUM, 1982, p.110).

4 Fonte: Séries estatísticas retrospectivas. Rio de Janeiro: IBGE, 1986. 
Com toda essa modernidade, surgem, ou melhor dizendo, adotam-se formas burguesas de desfrutar as atrações urbanas,

foram chegando novos estilos de vida, contrários aos rurais e mesmo aos patriarcais: o chá, o governo de gabinete, a cerveja inglesa, a botina Clark, o biscoito de lata. Também roupa de homem menos coloridas e mais cinzentas; o maior gosto pelo teatro que foi substituindo a igreja; pela carruagem de quatro rodas que foi substituindo o cavalo e o palanquim; pela bengala e pelo chapéude-sol que foram substituindo a espada de capitão ou de sargento-mor dos antigos senhores rurais. (FREIRE, 1936, p.574)

As pessoas consumiam mais, adquiriam hábitos refinados e estabeleciam padrões de exigência quanto à forma de usufruto das solicitações do mercado, do qual era exemplo notório a Rua do Ouvidor. Ela

era considerada o ponto elegante da cidade do Rio de Janeiro, porque a venda dos artigos importados da França, nas suas lojas, influenciava a todos, principalmente as mulheres - e a moda.

Macedo (1988, p.76) conta que

As senhoras fluminenses entusiasmaram-se pela Rua do Ouvidor, e foram intransigentes na exclusiva adoção da tesoura francesa. Nem uma desde 1822 se prestou mais a ir a saraus, a casamentos, a festas e reuniões sem levar vestido cortado e feito por modista francesa da Rua do Ouvidor.

Houve revolução econômica: os pais e os maridos viram subir a cinquenta por cento a mais a verba das despesas com os vestidos e os enfeites das filhas e das esposas. A rainha Moda de Paris firmou seu trono na Rua do Ouvidor.

Lá, todos queriam ser vistos por todos, acotovelando-se entre as suas estreitas calçadas.

Sem convites nem horários, nem etiquetas, a Rua do Ouvidor foi um ponto de encontros, um tablado de exibições elegantes, feira de vaidades e amores, um salão. (PINHO, 1942: 249) 
Um salão ao ar livre, convidativo às conversas informais e sussurradas, onde todos desejam estar. Machado faz um retrato fiel disso na crônica do dia 13 de agosto de 1893:

Vamos à rua do Ouvidor; é um passo. Desta rua ao Diário de Notícias é ainda menos. Ora, foi no Diário de Notícias que eu li uma defesa do alargamento da dita rua do Ouvidor, - coisa que eu combateria aqui, se tivesse tempo e espaço. Vós que tendes a cargo o aformoseamento da cidade alargai outras ruas, todas as ruas, mas deixai a do Ouvidor assim mesma - uma viela, como lhe chama o Diário, — um canudo, como lhe chamava Pedro Luiz. Há nela, assim estreitinha, um aspecto e uma sensação de intimidade. É a rua própria do boato. Vá lá correr um boato por avenidas amplas e lavadas de ar. O boato precisa do aconchego, da contigüidade, do ouvido à boca para murmurar depressa e baixinho, e saltar de um lado para outro.

Na rua do Ouvidor, um homem, que está à porta do Laemmert, aperta a mão do outro que fica à porta do Crashley, sem perder o equilíbrio. Pode-se comer um sandwich no Castelões e tomar um cálix de Madeira no Deroché, quase sem sair de casa. O característico desta rua é ser uma espécie de loja única, variada, estreita e comprida.

Depois, é mister contar com a nossa indolência. Se a rua ficar assaz larga para dar passagem a carros, ninguém irá de uma calçada a outra, para ver a senhora que passa, - nem a cor dos seus olhos, nem o bico dos seus sapatos, e onde ficará em tal caso "o culto do belo sexo", se lhe escassearem os sacerdotes. (ASSIS, 2008a , p.1007-8)

As transformações urbanas forjavam novas realidades e revelavam costumes mais soltos. É o que nos mostra uma passagem de O cortiço, de Aluísio Azevedo, obra ambientada nessa época:

As tinas estavam abandonadas; os coradouros despidos. Tabuleiros e tabuleiros de roupa engomada saíam das casinhas, carregadas na maior parte pelos filhos das próprias lavadeiras que se apresentavam agora quase todas de fato limpo. Os casaquinhos brancos avultavam por cima das saias de chita de cor. Desprezavam os grandes chapéus de palha e os aventais de aniagem; agora as portuguesas tinham na cabeça um lenço de ramagens vistosas e as brasileiras haviam penteado 
o cabelo e pregado nos cachos negros um ramalhete de dois vinténs. (AZEVEDO, 1978, p. 66-7)

A essas transformações - tanto às da elegante Rua do Ouvidor quanto às dos cortiços -, associava-se o projeto de formação de uma sociedade letrada, valorizando a leitura como o símbolo de instrução e como forma de socialização; não só a leitura em português, pois a prova de maior cultura era a leitura em francês. Era de bom tom falar e ler francês, sobre isso Macedo (1988, p.76) esclarece:

Como é sabido, cuidava-se ainda muito pouco da instrução do sexo feminino; pois bem, algumas senhoras fluminenses deram-se logo com interesse e gosto ao estudo da língua francesa.

Um dia um tio velho e rabugento perguntou à sobrinha que escapara de ficar analfabeta:

Menina, por que te meteste a aprender francês, quando ainda ignoras tanto o português?...

Ah, titio!... é tão agradável ouvir dizer très jolie! em português não há isso.

Aprender francês estava previsto na educação das mulheres brasileiras que tinham condições financeiras para isso. Os romances franceses eram lidos no original e faziam parte do lazer feminino. Mas, reafirma-se, apenas para a elite.

Machado de Assis, soube muito bem captar todas essas nuanças da cidade em suas crônicas, e Cadwell (2008, p.219) consegue sintetizar a obra do nosso autor ao afirmar que

De suas colunas e correspondências, vislumbramos ainda o Machado de Assis da vida diária - seus hábitos; gostos e desgostos; seu amor pela cidade natal, desalento pela falta de condições sanitárias; sua impaciência irônica com políticas desonestas, patentes de remédios, Sarah Bernhardt, o alto custo de morrer, oradores indigestos na hora da sesta e outros gloriosos produtos da civilização; seu ânimo em estender a mão a outros escritores brasileiros, iniciantes e inexperientes; seu orgulho da língua portuguesa. sua devoção apaixonada por Shakespeare; discussões literárias em chás da tarde; suas amizades; sua solidão após a morte da esposa. 


\section{A imprensa e o jornalista/cronista}

Gênero híbrido que se posiciona entre o jornalismo e a literatura, a crônica foi utilizada por Machado de Assis como meio para se comunicar com os seus leitores, entre 1858 e 1900. Em seu tempo, não havia muita diferenciação entre a atividade de literato e a de jornalista/cronista. Pode-se dizer que o escritor se encontrava numa fronteira, transportando ideias de um lado para o outro, enriquecendo o cronista com o homem das letras e vice-versa. Para o pesquisador John Gledson (1986, p.115), "é espantoso como se tem estudado pouco, de maneira mais séria, o jornalismo de Machado”.

Ao longo de sua longa - e profícua - trajetória como cronista, Machado escreveu também sobre a própria atividade, diagnosticando problemas e sugerindo soluções para uma adequada atuação da imprensa.

[...] a discussão do jornal reproduz-se também naquele espírito rude, com a diferença que vai lá achar o terreno preparado. A alma torturada da individualidade ínfima recebe, aceita, absorve sem labor, sem obstáculo aquelas impressões, aquela argumentação de princípios, aquela arguição de fatos. Depois uma reflexão, depois um braço que se ergue, um palácio que se invade, um sistema que cai, um princípio que se levanta, uma reforma que se coroa. (ASSIS, 2008b, p; 1036)

É importante saber, conforme analisa Barreto Filho (1997), que, no ofício de cronista, Machado de Assis começa a ouvir o seu "demônio interior" e a se expressar de acordo com a vontade de seu próprio espírito: "surgirá do cronista o contador de histórias da cidade, pilhérico, irônico, amargo ou evocativo" (BARRETO FILHO, 1997, p.100).

Segundo Afranio Coutinho (1966, p.15), a evolução perceptiva do cronista a respeito do jornalismo pode ser estendida à trajetória dos romances machadianos:

O desenvolvimento de Machado de Assis é um longo processo maturação, ao longo do qual vai acumulando experiência e fixando vivências, que gerarão o seu credo espiritual e estético e sua concepção técnica”.

Na juventude, nosso escritor foi um dos responsáveis pela formação e consolidação da imprensa no Brasil, considerando-a "a verdadeira forma da república do pensamento"5 (ASSIS, 2008b, p. 1009). Em 23 de outubro de 1859,

$5 \quad$ Texto "O jornal e o livro", publicado no Correio Mercantil, Rio de Janeiro, em 10 e 12 de janeiro de 1859. 
escreve o texto "A reforma pelo jornal", em que fundamenta a formação da imprensa brasileira:

A primeira propriedade do jornal é a reprodução amiudada, é o derramamento fácil em todos os membros do corpo social. Assim, o operário que se retira ao lar, fatigado pelo labor quotidiano, vai lá encontrar ao lado do pão do corpo, aquele pão do espírito, hóstia social da comunhão pública. (ASSIS, 2008b, p.1036)

Na crença machadiana, o jornalismo no Brasil oitocentista funcionaria como agente capaz de popularizar o saber, que antes se concentrava nas mãos de poucos, e de interferir nas decisões políticas, econômicas e sociais de uma nação, ao ambientar o espírito democrático e desarticular a "organização desigual e sinuosa da sociedade" (ASSIS, 2008b, p. 1035). Nesse texto de 23 de outubro de 1859, nosso escritor realizou, de forma acentuada, uma propaganda positiva da imprensa. Era preciso legitimá-la como uma necessidade vital, pois caberia a ela reformar a sociedade brasileira, que se encontrava no abismo da escravidão e do analfabetismo. Houaiss (1985, p. 137) nos lembra que "O ensino das primeiras letras foi precário até adentro do século XX, até 1920.”

Ainda nesse texto, Machado descreveu o jornalista como um personagem ímpar - um herói -, motivado por vínculos de paixão e estoicismo que o levam à busca da verdade e ao exercício da profissão, entendida como “missão", repleta de responsabilidade social. Porém, após construir tal paradigma, o escritor elabora um parecer bastante realista a respeito da atividade da imprensa no país: “o jornal aqui não está à altura da sua missão" (ASSIS, 2008b, p.1036). Schwarz (2000a), um profundo conhecedor da obra machadiana, comenta, sem se aprofundar, que o cronista se desilude com os ventos liberais e com os ideais do progresso e da igualdade difundidos pela imprensa, visto que ela aparece no Brasil do século XIX como um algo essencialmente político, e não social.

Para Sevcenko (1983, p.119),

O desenvolvimento do "novo jornalismo" representa, contudo, o fenômeno mais marcante na área da cultura, com profundas repercussões sobre o comportamento do grupo intelectual. Novas técnicas de impressão e edição permitem o barateamento extremo da imprensa. $\mathrm{O}$ acabamento mais apurado e o tratamento literário e simples da matéria tendem a tornar obrigatório o seu consumo cotidiano pelas camadas

6 Publicado no periódico O Espelho, Rio de Janeiro. 


\begin{abstract}
alfabetizadas da cidade [Rio de Janeiro]. Esse "novo jornalismo", de par com as revistas mundanas, intensamente ilustradas e que são o seu produto mais refinado, torna-se mesmo a coqueluche da nova burguesia urbana, significando o seu consumo, sob todas as formas, um sinal de bom-tom sob a atmosfera da Regeneração. Cria-se assim uma "opinião pública” urbana, sequiosa do juízo e da orientação dos homens de letras que preenchiam as redações. Os intelectuais, por sua vez, vendo aumentado o seu poder de ação social, anseiam levá-lo às últimas conseqüências. Pregam reiteradamente a difusão da alfabetização para a "redenção das massas miseráveis".
\end{abstract}

A propaganda positiva da imprensa foi o tema de algumas crônicas de Machado - as primeiras em que fez tal propaganda foram "O jornal e o livro" e "A reforma pelo jornal", de 1859. Despontava no Brasil, de então, uma jovem imprensa, juntamente com um novo cronista, Machado de Assis.

O escritor manifesta-se, por meio dessas crônicas, um entusiasta do progresso que deveria nortear a história das ideias e das ações necessárias ao arranjo moderno do pensamento liberal, propagado pelos ideais da Revolução Francesa (1789), que preconizava a busca pela democracia e pela garantia dos direitos humanos, com os princípios de liberdade, fraternidade e igualdade. Tais princípios foram importados pela elite brasileira e transformados em arcabouço teórico para implementar um possível ingresso do Brasil no conjunto dos países civilizados.

Machado de Assis - afirmando "O jornal é a liberdade, é o povo, é a consciência, é esperança, é trabalho, é a civilização. Tudo se liberta.” (ASSIS, 2008b, p.1011) - apresenta, com profunda convicção, o jornal como instrumento plural e democrático, capaz de fazer circular a multiplicidade de princípios que regeram politicamente a Revolução Francesa, fazendo com que esta sirva de paradigma ideológico para a busca da cidadania mesmo em terras marcadas pela escravidão, como foi o caso do Brasil oitocentista. O cronista fluminense acredita no potencial do jornal como agente capaz de construir um clima democrático que favorecesse o "adiantamento moral da humanidade" (idem, p. 1007). Referindo-se a uma obra do escritor francês Pelletan como "livro de ouro", o cronista vai "bebericar nessa fonte, aceitando a tese da contínua perfectibilidade do espírito humano" (FACIOLI, 1982, p. 19). Machado afirma que o espírito humano foi realçado e refinado pelo progresso trazido pelo livro e alcançou mais transparência com o jornal. Entende, ainda, que este, ao desenvolver e ampliar o espectro da audiência, incentiva a prática da discussão de todo e qualquer fato social. Ao perguntar 
“O jornal matará o livro? O livro absorverá o jornal?” (ASSIS, 2008b, p. 1007), ele toma consciência do momento em que o jornal se firma como suporte moderno capaz de difundir, para um grande número de pessoas, os fatos e suas repercussões, de maneira dinâmica e interativa.

Para evitar desentendimentos, Machado esclarece: "Admitido o aniquilamento do livro pelo jornal, esse aniquilamento não pode ser total. Seria loucura admiti-lo." (idem, p. 1011). Quando um novo meio surge e se fortalece como tendência mais usual do que o antigo, cria-se uma expectativa na própria opinião pública de que este ficará tão obsoleto que cairá em desuso ou será menos apreciado. Segundo nosso autor, não é em termos comparativos, que se deve avaliar a qualidade e o alcance do livro e do jornal, pois cada meio tem a sua especialidade e carrega a sua própria mensagem ${ }^{7}$.

$\mathrm{Na}$ discussão da polêmica entre os suportes livro e jornal, é preciso estar atento à forma como Machado de Assis se relacionou com eles. Para Zilberman (2004, p.25),

O fato de participar ativamente da imprensa fez de Machado um produtor assíduo, regular e constante de textos, que, muitas vezes, se repetiam, eram reformatados ou então alterados, quando transportados do suporte jornalístico para o livro. Embora, na juventude, tenha sido fervoroso adepto do jornal, sabia que o livro tinha durabilidade maior e alcançava um público mais distante e exigente, de modo que requeria cuidados e esmeros especiais.

Na visão de Sá (2007, p.18), todo cronista, ao transferir seu texto do jornal para o livro, procura adaptá-lo ao novo veículo; e afirma: “o escritor está buscando fazer da tenda precária e cigana uma casa sólida e mais duradoura”.

Machado, comparando livro e jornal, não vislumbra um cenário de decadência do gosto ou das letras. É, ao contrário da decadência, uma evolução,

7 O pensador alemão Oswald Spengler (1880-1936), ao contrário de Machado de Assis, acreditava que o livro podia ser ameaçado pela concorrência da revista de compilações e, sobretudo, pelo jornal: "A época do livro está enquadrada entre o sermão e o periódico. O mundo dos livros, com sua abundância de pontos de vista, que obrigava o pensamento à crítica e à seleção, em realidade só existe agora para círculos pequenos. O povo lê um jornal, seu jornal, que, em milhões de exemplares entra, todos os dias, em todas as casas, mantém os espíritos sob seu encanto e faz que se esqueçam os livros [...]. A democracia substituiu, na vida espiritual das massas, o livro pelo jornal. (SPENGLER, apud CORBISIER, 1950, p.33) 
um sinal dos tempos; é o primeiro indício de uma era, em que se irá caminhar para o que é breve, condensado, bem digerido. Seguindo a definição de Araújo (2002, p. 36), "se o livro é o vislumbre para a entrada no mundo moderno; o jornal é a efetivação plena da modernidade."

Segundo Machado, o jornal supera o livro justamente por sua distribuição mais equitativa e democrática: "o jornal é mais que um livro, isto é, está mais nas condições do espírito humano" (ASSIS, 2008b, p. 1010). O cronista percebe a nova era que se anuncia com o advento do jornal - que, utilizando uma escala de tempo mais dinâmica, interpreta, resume e divulga o que fora, durante séculos, o privilégio e o monopólio do livro.

O jornal é denominado por Machado de Assis como "literatura comum". Sob essa nomenclatura, ele informa, subliminarmente, que o cronista deve buscar uma linguagem acessível, mais simples que a do livro, próxima à oralidade, porém mesclada com elementos da literatura culta a fim de aprimorar o estilo e potencializar a conversa com o leitor. Devido à sua marca temporal, o jornal deve ser responsável por acompanhar e transmitir o calor e as repercussões do fato no dia seguinte ao ocorrido para que o leitor tenha acesso de forma ágil e dinâmica à "frescura das ideias" e ao "fogo das convicções".

Sendo assim, o jornalismo pode ser considerado uma forma literária feita à queima roupa,

O jornal, literatura cotidiana [...] é reprodução diária do espírito do povo, o espelho comum de todos os fatos e de todos os talentos, onde se reflete, não a idéia de um homem, mas a idéia popular, esta fração da idéia humana. (ASSIS, 2008b, p. 1010)

Machado crê numa imprensa atuante; alimentada pelo espírito revolucionário, um veículo capaz de tornar público, isto é, de conhecimento de todos, em sua periodicidade, por meio do balanço dos acontecimentos da semana, o teor e o calor das diversas ideias e suas repercussões no tocante à realidade brasileira. Em sua missão primordial de democratizar a informação e alimentar a opinião pública, o jornal chega a significar, no julgamento do cronista, como anteriormente citado, "a verdadeira forma da república do pensamento".

A definição machadiana de jornal - que buscava legitimar o veículo como meio capaz de responder às diversas demandas do espírito coletivo da sociedade brasileira - encontra eco na atualidade: Pignatari (1995, p.223), discorrendo sobre a utilidade pública do jornal e dos outros meios de comunicação, afirma:

Acho que os meios de comunicação, com lastreamento básico na imprensa e prolongamento necessário na televisão e na mídia eletrônica 
em geral, se constituem na verdadeira universidade aberta do povo, em todos os países, mas especialmente nas nações terceiro-mundistas.

Ao associar informação e educação e ao considerar a imprensa como "universidade aberta do povo", Pignatari aproxima-se da definição machadiana da imprensa como "república do pensamento". Assim para Machado, a imprensa deveria atuar em duas frentes: educar o povo, ensinando-o a pensar, e demolir as estruturas aristocráticas em nome da democracia.

Ao depositar no jornal a esperança de que o século XIX responderia aos anseios libertários da Revolução Francesa, Machado de Assis desejava que o progresso e a democracia - confirmados pelo jornal - pudessem trazer ânimo e disposição para que houvesse um ciclo de reformas capazes de modificar radicalmente a estrutura social oligárquica presente no Brasil oitocentista.

O entusiasmo daquele Machadinho de 1859 pela novidade do jornal deita raízes não apenas na crença de que esse novo veículo de ideias seria o único capaz de acompanhar a urgência das mudanças modernas, mas também na incumbência do jornal em reformar toda a sociedade, pelo debate público e livre em suas páginas. O jornal é mais que simples informação, é "esta alavanca que Arquimedes pedia para abalar o mundo, e que o espírito humano, esse Arquimedes de todos os séculos, encontrou." (ASSIS, 2008b, p.1007).

$\mathrm{O}$ objetivo de Machado de Assis é legitimar a imprensa junto à sociedade brasileira, atribuindo-lhe o papel de instituição articuladora e agente privilegiado de reformas essenciais para o País. Ele inicia a sua crônica "A reforma pelo jornal" com a frase: "Houve uma coisa que fez tremer as aristocracias, mais do que os movimentos populares; foi o jornal." (idem, p. 1035). Pereira (1988, p.73), sobre essa crônica, afirma que Machado

deixava bem patentes as tendências liberais, louvando o jornal pela sua ação democratizante, declarando-se adversário das aristocracias. Exigia a divulgação da cultura, o esclarecimento das massas".

O cronista aponta para a disseminação das ideias, das discussões, entendida como possibilidades iguais para diferentes pessoas, por intermédio da leitura do livro e, em seguida para o avanço dessa disseminação através da página do jornal, local por excelência do debate de ideias - está aí o papel importante que desempenhou - e desempenha até hoje - a imprensa na segunda metade do século XIX.

A leitura dos textos "O jornal e o livro" e "A reforma pelo jornal" permitenos compreender um importante período da história, passada a limpo pela pena de um dos nossos maiores cronistas. Nas palavras de Schwarz (2000a, p.241), 
[...] a sua fórmula narrativa atende meticulosamente às questões ideológicas e artísticas do Oitocentos brasileiro, ligadas à posição periférica do país. Acertos, impasses, estreitezas, ridículos, dos predecessores e dos contemporâneos, nada se perdeu, tudo se recompôs e transfigurou em elemento de verdade.

\section{A intra e a intertextualidade da crônica machadiana}

As disputas travadas, por meio do jornal, entre os vários literatos e cronistas levam-nos à percepção de um outro aspecto muito importante de estratégia linguística: a intertextualidade. Um autor escrevia, o outro revidava, e assim a história ia-se construindo. A intertextualidade que pretendemos destacar em nosso trabalho é aquela existente entre as crônicas de Machado de Assis e os textos de outros escritores.

Machado, em suas crônicas, faz referências aos seus escritores preferidos, entre eles Willian Shakespeare, Joseph Ernest Renan, Blaise Pascal, Arthur Schopenhauer, Michel de Montaigne, Platão, entre outros, além de citações bíblias - geralmente retiradas do livro de Eclesiastes, do Antigo Testamento, cremos por ser um dos livros poéticos e sapienciais.

Faz, também, citações em latim, que dá ao seu texto um cunho erudito:

Dei o grito. Tinha achado o segredo da substituição do nome. Com efeito, rocló vem do francês roquelaure, designação de um capote. Portugal recebeu de França o capote e o nome, e ficou com ambos, mas foi modificando o nome. Tal qual aconteceu com robe de chambre. A mudança proposta agora no artigo a que me refiro, ficaria sem sentido, se não fosse intenção do autor, suponho eu, curar a dentada do cão com o pêlo do mesmo cão. Similia similibus curantur. (ASSIS, 2008c, p.866)

Em 16 de dezembro de 1883, Machado cita três filósofos, dentre os muitos que considera "homens superiores":

Quer me parecer que a idéia do meu amigo é da mesma família da de Platão, Renan e Schopenhauer, uma forma aristocrática de governo composto de homens superiores, espíritos cultos e elevados, e nós que fôssemos cavar terra. Não! mil vezes não! A democracia não gastou o seu sangue na destruição de outras aristocracias, para acabar nas mãos de uma oligarquia ferrenha, mais insuportável que todas, porque os 
fidalgos de nascimento não sabiam fazer epigramas, e nós os medíocres e medalhões padeceríamos nas mãos dos Freitas e dos Alencares, para não falar dos vivos. (ASSIS, 2008c, p. 507-8)

Essas apropriações de ideias filosóficas, psicológicas, bíblicas servem para dar força às suas próprias palavras, ou justificar o comentário de um assunto em que ele, Machado, faz as suas reflexões filosóficas, pois, como nos informa Coutinho (1966, p. 124), seus textos apresentam "uma atmosfera filosófica".

Machado mantém intertextualidade, também, com escritos de José de Alencar. E citando-o - na mesma crônica em que fala de Platão, Renan e Schopenhauer -, coloca-o como "chefe de nossa literatura", revelando a reverência a ele (tanto quanto aos pensadores grego, francês e alemão).

As conversas com Alencar na livraria Garnier foram determinantes para que Machado lapidasse a sua expressão como escritor, incluindo aí sua atuação marcante como cronista. Machado retrata esses diálogos como memoráveis e lembra-se de ambos sentados em frente à rua, tratando de arte e poesia, de estilo e imaginação, que valiam todas as canseiras do mundo. A morte de Alencar, em 12 de dezembro de 1877, abalou Machado não só por ter perdido um amigo, mas também por perder uma referência que fora crucial em seus primeiros passos como escritor e jornalista:

Toda a história destes quinze dias está resumida em um só instante, e num acontecimento único: a morte de José de Alencar. Ao pé desse fúnebre sucesso, tudo o mais empalidece. Quando começou a correr a voz de que o ilustre autor do Guarani sucumbira ao mal que de há muito o minava, todos recusavam dar-lhe crédito; tão impossível parecia que o criador de tantas e tão notáveis obras pudesse sucumbir ainda em pleno vigor do espírito. (ASSIS, 2008c, p. 393)

Enquanto jovem, Machado de Assis é contemporâneo de um Alencar com carreira já consolidada, e aclamado pela opinião pública como o grande cronista do Rio de Janeiro de seu tempo. Como parâmetro estilístico, há momentos em que Machado parodia certos lugares textuais já visitados anteriormente por Alencar. Entretanto, isso não representa uma limitação temática e de expressividade, em que Machado se comporta como refém, reproduzindo meramente, sem subverter, a dinâmica do ofício do cronista, construída por Alencar. Tanto é que, com o transcorrer da experiência machadiana como cronista, ele desenvolve uma identidade própria nos seus escritos, apresentando um mérito singular diante dos leitores e não se acomodando, portanto, na sombra deixada por José de Alencar. 
Machado de Assis, numa de suas crônicas, compara o folhetinista, e suas visitas aos variados assuntos, ao colibri que passeia por diversas flores. Tal metáfora é tomada de empréstimo de José de Alencar: este ao indicar que, da mesma forma como o papel do colibri é sugar o mel das flores, o do folhetinista é sugar "a graça, o sal e o espírito que deve necessariamente descobrir no fato o mais comezinho!” (ALENCAR, 1960, p.648).

Trabalhando a intertextualidade, Machado escreve:

O folhetinista, na sociedade, ocupa o lugar de colibri na esfera vegetal; salta, esvoaça, brinca, tremula, paira e espaneja-se sobre todos os caules suculentos, sobre todas as seivas vigorosas. Todo o mundo lhe pertence; até mesmo a política.

Assim aquinhoado pode dizer-se que não há entidade mais feliz neste mundo, exceções feitas. Tem a sociedade diante de sua pena, o público para lê-lo, os ociosos para admirá-lo, e a bas-bleus para aplaudilo.

Todos o amam, todos e admiram, porque todos têm interesse de estar de bem com esse arauto amável que levanta nas lojas do jornal a sua aclamação de hebdomadário. (ASSIS, 2008b, p. 1022-3)

Machado, ainda nesse trabalho de trazer "o outro" para o seu texto, faz a mesma coisa com as suas próprias crônicas, ou seja; referência uma noutra, num processo que podemos chamar de intratextualidade. Ele utiliza esse recurso para fazer com que seu leitor, que o segue semanalmente em sua coluna, possa ligar com mais facilidade um assunto a outro, que já tenha sido comentado noutro tempo. Isso ocorre com muita frequência:

Falei na minha crônica passada de uma reunião literária para instituir leituras públicas. Essa reunião não se efetuou como era de desejar, mas, pelo que me consta, trata-se de dar começo a propaganda da idéia. Já a aplaudi rápida e sinceramente. O que tenho de fazer agora é transcrever aqui a carta pela qual o Sr. A. de Pascual, iniciador da idéia, convidou para a reunião o poeta A. E. Zaluar. Nessa carta vão, apontados a utilidade e os exemplos das leituras públicas. O leitor, se é literato, fica convocado por ela. (ASSIS, 2008c, p. 98)

E nesta outra crônica, a intertextualidade se dá pela temática: 
Hão de lembrar-se da minha aventura espírita, e da promessa que fiz, de iniciar-me na nova Igreja. Vão ver agora o que me aconteceu.

Fui iniciado quinta-feira, às nove horas da noite, e não conto nada do que se passou, porque jurei calá-lo, por todos os séculos dos séculos. Uma vez admitido no grêmio, preparei as malas para ir estabelecer-me em Santo Antônio de Pádua. (ASSIS, 2008c, p.640)

\section{Consideração final}

Nada passa incólume pelas lentes de Machado de Assis, um observador sempre atento e crítico, desde suas primeiras crônicas. Em 1900, ele encerra sua participação como jornalista/cronista, escrevendo, em 11 de novembro, a última crônica, que fecha a seção A Semana, do Gazeta de Notícias; depois disso, dedica-se exclusivamente aos seus romances. $O$ excerto que segue é dessa última crônica:

[...] fui à casa de um leiloeiro, que ia vender objetos empenhados e não resgatados. Permitam-me um trocadilho. Fui ver o martelo bater no prego. Não é lá muito engraçado, mas é natural, exato e evangélico. Está autorizado por Jesus Cristo: Tu es Petrus, etc. Mal comparando, o meu ainda é melhor. O da Escritura está um pouco forçado, ao passo que o meu, - o martelo batendo no prego, - é tão natural que nem se concebe dizer de outro modo. Portanto, edificarei a crônica sobre aquele prego, no som daquele martelo.

Havia lá broches, relógios, pulseiras, anéis, botões, o repertório de costume.

Havia também um livro de missa, elegante e escrupulosamente dito para missa, a fim de evitar confusão de sentido. Valha-me Deus! até nos leilões persegue-nos a gramática. Era de tartaruga, guarnecido de prata. Quer dizer que, além do valor espiritual, tinha aquele que propriamente o levou ao prego. Foi uma mulher que recorreu a esse modo de obter dinheiro. Abriu mão da salvação da alma, para salvar o corpo, a menos que não tivesse decorado as orações antes de vender o manual delas. Pobre desconhecida! Mas também (e é aqui que eu vejo o dedo de Deus), mas também quem é que lhe mandou comprar um livro de tartaruga com ornamentações de prata? Deus não pede tanto; 
bastava uma encadernação simples e forte, que durasse, e feia para não tentar a ninguém. Deus veria a beleza dela. (ASSIS, 2008b, p. 1332)

Machado de Assis finaliza sua carreira de cronista mostrando toda sua verve, ao desabafar:

Havia também um livro de missa, elegante e escrupulosamente dito para missa, a fim de evitar confusão de sentido. Valha-me Deus! até nos leilões persegue-nos a gramática. (ASSIS, 2008b, p. 1332)

Com isso, fica claro que Joaquim Maria Machado de Assis tornou-se, sim, grande e merecedor do título de escritor universal - de seu tempo e de todos os tempos.

\section{REFERÊNCIAS}

ALENCAR, José de. Ao correr da pena. Obra completa. Rio de Janeiro: Nova Aguilar, 1960, $4 \mathrm{v}$.

ARAÚJO, R. Edgar Allan Poe: um homem em sua sombra. São Paulo: Ateliê Editora, 2002. ARRIGUCCI JR.. Davi. Fragmentos sobre a crônica. In: Boletim Bibliográfico Biblioteca Mário de Andrade. São Paulo: Secretaria Municipal de Cultura; Departamento de Bibliotecas Públicas, v. 46, n. 1/4, jan./dez. 1985.

ASSIS, Machado de. Obra Completa, em quatro volumes - V.2. Organização: Aluizio Leite Neto, Ana Lima Cecilio, Heloisa Jahn. 2a ed. Rio de Janeiro: Nova Aguilar, 2008a. . Obra Completa, em quatro volumes - V.3. Organização: Aluizio Leite Neto, Ana Lima Cecilio, Heloisa Jahn. $2^{\mathrm{a}}$ ed. Rio de Janeiro: Nova Aguilar, $2008 \mathrm{~b}$.

. Obra Completa, em quatro volumes - V.4. Organização: Aluizio Leite Neto, Ana Lima Cecilio, Heloisa Jahn. $2^{a}$ ed.Rio de Janeiro: Nova Aguilar, 2008c.

AZEVEDO, Aluísio. Casa de pensão. São Paulo: Três, 1973.

. O cortiço. São Paulo: Martins, 1978.

BARRETO FILHO. "O romancista". In: COUTINHO, Afranio (Org.). Machado de Assis: obra completa. Rio de Janeiro: Nova Aguilar, 1997, 1 v.

BASBAUM, Leôncio. História sincera da República: das origens até 1889. v.1. $4^{\mathrm{a}}$ ed. São Paulo: Alfa-Ômega, 1982.

CADWELL, Hellen. Otelo brasileiro de Machado de Assis: um estudo de D. Casmurro. $2^{\mathrm{a}}$ ed. Tradução Fábio Fonseca de Melo. Cotia: Ateliê editorial, 2008.

CANDIDO, Antonio. A vida ao rés-do-chão. In: A crônica: o gênero, sua fixação e suas transformações no Brasil. Campinas, SP: Editora da UNICAMP; Rio de Janeiro:

Fundação Casa de Rui Barbosa, 1992.

CARVALHO, José Murilo de. Os bestializados. São Paulo: Companhia das Letras, 1991.

CHARTIER, Roger. A História cultural: entre práticas e representações. Rio de Janeiro:

Difel, 1990. 
COUTINHO, Afranio. Machado de Assis na literatura brasileira. Rio de Janeiro: Livraria São José, 1966.

. A literatura no Brasil. 2a ed. Vol. VI. Rio de Janeiro: Sul Americana, 1971.

DEL PRIORE, Mary. Histórias íntimas: sexualidade e erotismo na história do Brasil. São Paulo: Planeta, 2011.

FACIOLI, Valentim. A crônica. In: BOSI, Alfredo et al. Machado de Assis. São Paulo: Ática, 1982.

FARIA, João Roberto. Machado de Assis e o teatro de seu tempo. In: FARIA, João Roberto (Org.). Machado de Assis: do Teatro - textos críticos e escritos diversos.

São Paulo: Perspectiva, 2008. - (Coleção textos; 23)

FRANCO, Gustavo H.B. A economia em Machado de Assis: o olhar oblíquo do acionista. Rio de Janeiro: Jorge Zahar, 2007.

FREIRE, Gilberto. Sobrados e mucambos. Tomo II. $7^{\text {a }}$ ed. Rio de Janeiro: José Olympio, 1936.

GLEDSON, John. Machado de Assis: ficção e história. Tradução de Sônia Coutinho. Rio de Janeiro: Paz e Terra, 1986.

HELLER, Agnes. O cotidiano e a história. 8 $8^{\text {a }}$ ed. São Paulo: Paz e Terra, 2008.

HOUAISS, Antônio. O Português no Brasil. Rio de Janeiro: UNIBRADE, 1985.

MACEDO, Joaquim Manuel de. Memórias da Rua do Ouvidor. Brasília: UnB, 1988. [1 $1^{\text {a }}$ ed. de 1878 ]

MOISÉS, Massaud. A criação literária. $3^{\mathrm{a}}$ ed. São Paulo: Melhoramentos, 1970.

PESAVENTO, Sandra Jatahy. História e literatura: uma velha-nova história. In: Nuevo Mundo Mundos Nuevos. Debates, 2006. Disponível em:

http://nuevomundo.revues.org/1560 (acesso em 28/01/2006).

. Machado de Assis: estudo crítico e biográfico. Belo Horizonte: Itatiaia; São

Paulo: Editora da Universidade de São Paulo, 1988.

PIGNATARI, Décio. Ideologia dos meios de massa. In: Letras, artes, mídia. São Paulo:

Globo, 1995.

PINHO, Wanderley. Salões e dama do Segundo Reinado. $4^{\mathrm{a}}$ ed. São Paulo: Martins, 1942.

SÁ, Jorge de. A Crônica. São Paulo: Editora Ática, 2007.

SABINO, Fernando. Última crônica. In: A companheira de viagem. Rio de Janeiro: Editora do Autor, 1965.

SCHWARZ, Roberto. Um mestre na periferia do capitalismo. $4^{\text {a }}$ ed. São Paulo: Duas Cidades/34, 2000a.

SEVCENKO, Nicolau. Literatura como missão: tensões sociais e criação cultural na Primeira República. São Paulo: Brasiliense, 1983.

ZILBERMAN, Regina. Minha theoria das edições humanas: Memórias Póstumas de Brás Cubas e a poética de Machado de Assis. In. ZILBERMAN, Regina et al. As pedras e o arco: fontes primárias, teoria e história da literatura. Belo Horizonte: Editora UFMG, 2004. 